\title{
Serial studies of 100 patients with chronic airway obstruction in London and Chicago
}

\author{
N. L. JONES, B. BURROWS, A ND C. M. FLETCHER \\ From the Royal Postgraduate Medical School, London, and the University of Chicago Hospitals
}

One hundred patients with chronic airway obstruction, 50 in Chicago and 50 in London, were studied by standardized techniques in 1961 . The results of the initial studies, previously reported, showed that the patients in the two cities were similar; using clinical and physiological criteria based on pathological studies, the patients were divided into three types-emphysematous type $A$, bronchial type B, and an indeterminate type $X$. The patients were studied again in succeeding years, 1962-65. During this time 26 died, 19 due to their respiratory disease ; these 19 patients were initially more breathless, had a higher incidence of cor pulmonale, and had more severe airway obstruction and higher carbon dioxide pressures than the remainder. Type $B$ patients (mortality $36 \%$ ) had a worse prognosis than either type A $(15 \%)$ or type $X(12 \%)$. Of the measurements made, high carbon dioxide pressures were most closely related $(\mathbf{P}<0.001)$ to mortality.

During the period of follow-up about one-third of the patients who did not die became more short of breath and developed more severe airway obstruction and carbon dioxide retention: about $10 \%$ showed definite improvement in symptoms and pulmonary function. The F.E.V.1.0 declined on average by $46 \mathrm{ml} . /$ year, $4.8 \%$ of the initial value ; V.C. declined by $120 \mathrm{ml}$./year, $4.0 \%$ of the initial value ; mixed venous $\mathrm{PCO}_{2}$ increased $1 \mathrm{~mm}$. $\mathrm{Hg} /$ year.

The changes that occurred during this time confirmed the previously reported similarity between the patients attending the two clinics. Although the incidence of bronchitic exacerbations was similar in the two cities, such illnesses in the London patients led to more frequent and more prolonged incapacity.

In 1961 a joint study of patients with chronic airway obstruction was begun in London and Chicago. The series comprised 50 patients from the Bronchitis Clinic at Hammersmith Hospital and 50 from the Emphysema Clinic at the University of Chicago Hospitals. The patients were men aged between 45 and 65 years with irreversible airway obstruction (forced expiratory volume less than 1.51 . in the first second). They were studied by the same standardized clinical and physiological techniques in the two clinics and were found to present a broadly similar range of clinical and physiological abnormality (Fletcher, Jones, Burrows, and Niden, 1964). We report here the results of yearly studies on these patients during the following three years. The clinical and physiological changes have been compared in the two clinics and in the main clinical types of patient.

\section{METHODS}

The patients studied are those described by Burrows, Niden, Fletcher, and Jones (1964); in that study they were divided into group A (emphysematous type), group B (bronchial type), and group X (indeterminate type) according to provisional criteria. As a result of a subsequent clinicopathological study (Burrows, Fletcher, Heard, Jones, and Wootliff, 1966) these criteria have been modified to provide a more accurate prediction of the severity of emphysema. The patients have been regrouped according to the new criteria (Appendix I, p. 334); this results in a larger number of type $A$ and rather fewer type $B$ patients (Table I), but the incidence of the types remains similar in the two clinics.

Questionnaires were used to obtain the clinical history and were of two types. The first was used at the yearly follow-up appointment and was identical in most respects to the questionnaire used in the original study (Fletcher et al., 1964); in addition, the 


\section{T A B L E I}

CLINICAL TYPES OF PATIENT

A. Effect of regrouping patients using new criteria

\begin{tabular}{|c|c|c|c|c|}
\hline \multirow{2}{*}{ New Criteria } & \multicolumn{4}{|c|}{ Original Criteria } \\
\hline & Type A & Type B & Type X & Total \\
\hline Type A (emphysematous) & 23 & 1 & 16 & 40 \\
\hline Type B (bronchial) & - & 19 & 6 & 25 \\
\hline Type X (indeterminate) & 4 & 15 & 16 & 35 \\
\hline Total $\quad$. & 27 & 35 & 38 & 100 \\
\hline
\end{tabular}

B. Incidence in the two clinics

\begin{tabular}{c|c|c|c}
\hline Type of Patient & London & Chicago & Total \\
\hline A & 22 & 18 & 40 \\
B & 13 & 12 & 25 \\
X & 15 & 20 & 35 \\
\hline Total & 50 & 50 & 100 \\
\hline
\end{tabular}

patients were asked whether their cough, sputum production, and dyspnoea were 'definitely better', 'about the same', or 'definitely worse' than in the previous year. Questions were asked about the number of chest illnesses that had occurred during the year which were severe enough to cause loss of time from work or had made the patient go to bed. A second questionnaire, which dealt with such illnesses in detail, was sent to patients every three months in 1962-63 and was completed by them. A clinical examination identical to the original one was carried out each year, including a simple step exercise tolerance test: chest radiographs and electrocardiograms were obtained and graded as in the original study.

Yearly measurements were made of vital capacity (V.C.), forced expiratory volume in the first second (F.E.V.1.0), both before and after nebulized bronchodilator and mixed venous carbon dioxide pressure $\mathrm{P}_{\mathrm{V}} \mathrm{CO}_{2}$ ) (Campbell and Howell, 1960). The methods used to obtain the initial physiological data have already been described (Fletcher et al., 1964). Serial physiological measurements were subjected to regression analysis. Linear regressions were obtained by the least squares technique with the aid of a high-speed digital computer. Correlations between various physiological and clinical observations were also calculated by the computer.

\section{RESULTS}

Slight differences in the time of recruitment in the two clinics led to a difference in the average period of follow-up - 34.6 months in London compared to 30.9 months in Chicago-but all the patients were followed for at least two years. Although there were some minor omissions in the data collected there were no complete lapses in follow-up; only one patient failed to return foro the first yearly follow-up and the two- and three-으 year follow-up examinations were attended by all 78 patients who had survived until that time.

DEATHS Eight patients died during the first year, five during the second, and 13 during the third, a total of $26 ; 12$ were London and 14 were $\vec{\omega}$ Chicago patients. In 19 patients ( 9 from London, $\stackrel{\circ}{ }$ 10 from Chicago) death was directly attributable $\vec{x}$ to the lung disease and in seven patients to otheri causes (two from cerebrovascular accidents, two from carcinoma, one from myocardial infarction, $\dot{\omega}$ one post-operatively, and one by suicide). The $N$ characteristics of the 19 patients who died fromo cardiorespiratory causes were broadly similar inthe two clinics, allowing for the small numbers.

\section{T A B L E I I}

COMPARISON OF THE CHARACTERISTICS OF PATIENTS WHO DIED FROM CARDIORESPIRATORY CAUSES WITHO THE REMAINDER OF THE SERIES.

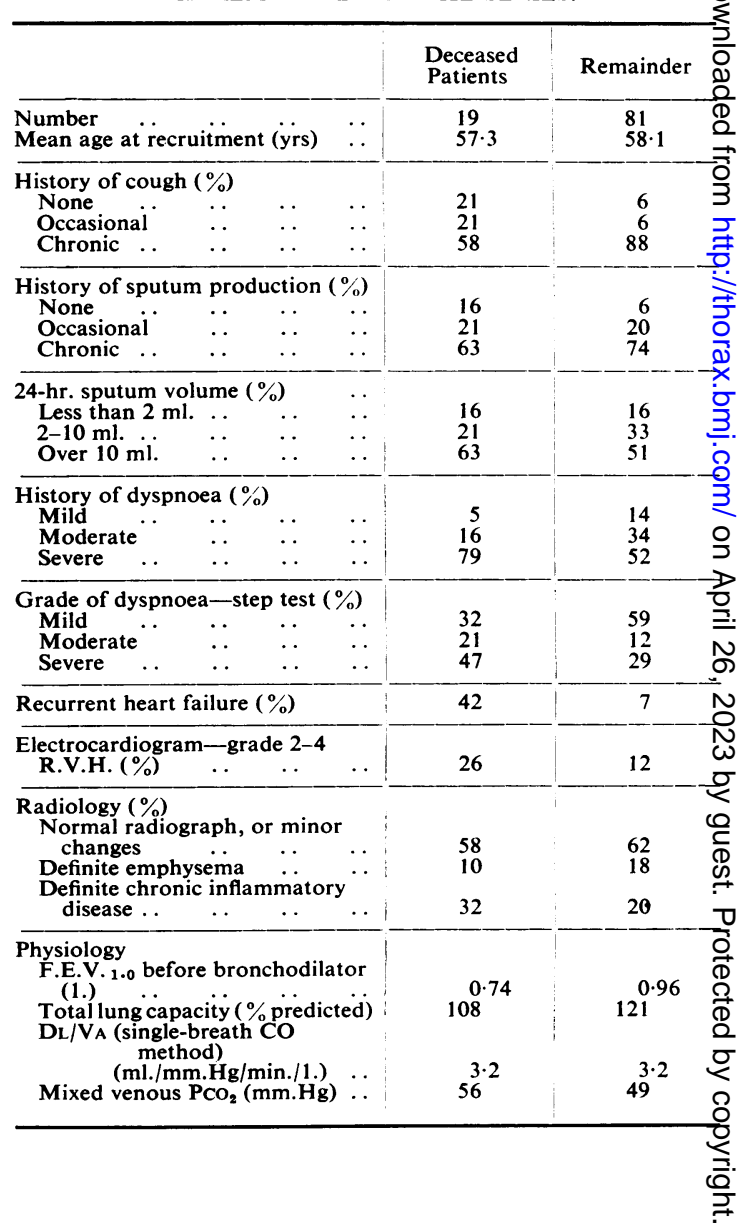


A comparison between them and the remainder of the series (those who survived combined with those who died from other causes) is shown in Table II. The patients who died cardiorespiratory deaths were of a similar average age; although there were slight differences in the histories of cough, the history of sputum production and the measured sputum volume were similar; they

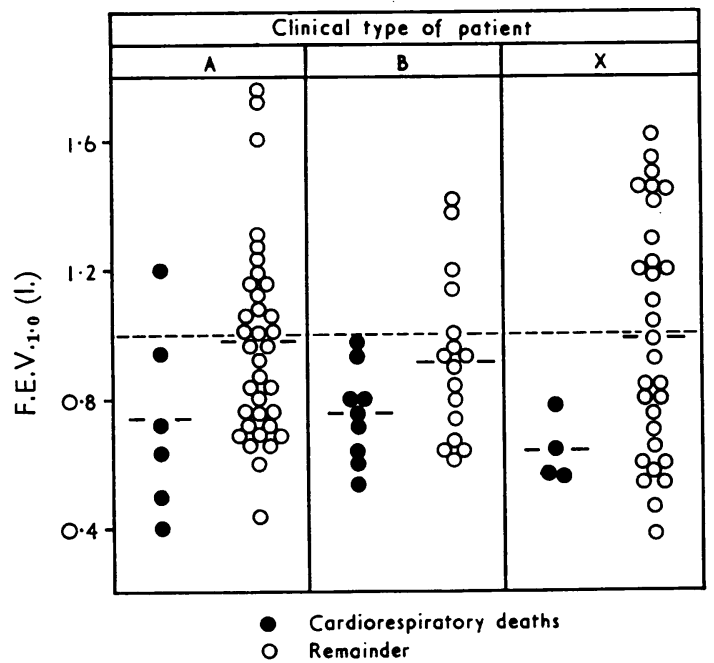

FIG. 1. F.E.V.1.0 in the three clinical types of patient. Mean F.E.V.1.0 shown by horizontal bars: F.E.V.1.0 of 1 litre shown by dotted line.

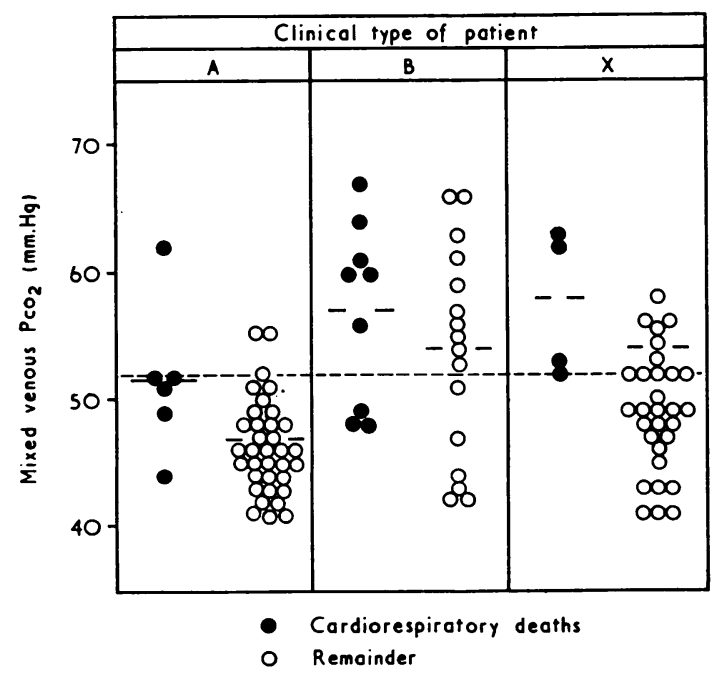

FIG. 2. Mixed venous $\mathrm{PCO}_{2}$ in the three clinical types of patient. Upper limit of normal $P_{\bar{v}}^{-} \mathrm{CO}_{2}$ shown by dotted line. were more short of breath and showed more severe dyspnoea in the step test. Radiographic changes of chronic inflammatory disease, but not of emphysema, were more common than in the remainder. Congestive heart failure occurred more frequently in the patients who died and E.C.G. changes of right ventricular hypertrophy were more common than in the remainder. The F.E.V. $\cdot_{1 \cdot 0}$ (Fig. 1) and V.C. were lower, as was the total lung capacity (T.L.C.), but the mean diffusing capacity for $C O\left(D_{L} / V_{A}\right)$ was the same; the mean mixed venous $\mathrm{PCO}_{2}$ was higher in the patients who died (Fig. 2). Statistical analysis of the data showed that death was most closely related to the initial $\mathrm{P}_{\bar{v}} \mathrm{CO}_{2}(\mathbf{P}<0.001)$ but also showed a correlation with the initial V.C. $(P<0.05)$ and F.E.V $\cdot_{1 \cdot 0}(P<0.05)$; stepwise multiple regression showed that after the $\mathrm{PCO}_{2}$ had been taken into account neither F.E.V. $\cdot_{\cdot \cdot 0}$ nor V.C. were significantly correlated with death; in contrast, the relationship between death and $\mathrm{P}_{\overline{\mathrm{V}}} \mathrm{CO}_{2}$ was still significant even after the F.E.V $\cdot_{\cdot 1 \cdot 0}$ and V.C. had been considered.

CHANGES IN SYMPTOMS Some patients who showed an apparent change for the better or for the worse when their answers to questions about the present severity of symptoms were compared with their answers in previous years, answered the question as to whether they were 'better' or 'worse' in these respects in a contrary sense. Responses to both types of questions were examined; when the answers were contradictory it was assumed that no significant change in the symptom had occurred.

Comparing the clinical course in the two clinics (Table III), it was found that Chicago patients more frequently claimed improvement in cough and sputum production but admitted to increasing breathlessness more often than London patients. These differences were not supported by measurements of sputum volume, assessment of dyspnoea in the step test, or measurement of F.E.V. $\cdot_{\cdot 1 \cdot 0}$, all of which showed similar progression in the two clinics. Patients often reported an improvement in sputum production without showing any change in measured 24-hour sputum volume (Table IVA). Deterioration in symptomatic breathlessness during the follow-up period was significantly correlated $(r=+0.387 ; \quad P<0.001)$ with deterioration in ability to perform the step test (Table IVB) even though deterioration was not apparent in some patients because their symptom or performance grading was at the most severely impaired level at the initial examination. Deterioration in exercise performance was signi- 
T A B LE I I I

CHANGES DURING TWO TO THREE YEARS

\begin{tabular}{|c|c|c|c|c|c|c|}
\hline & \multirow[b]{2}{*}{ Total } & \multicolumn{2}{|c|}{ Clinics } & \multicolumn{3}{|c|}{ Clinical Types } \\
\hline & & $\begin{array}{l}\text { Lon- } \\
\text { don }\end{array}$ & $\begin{array}{l}\text { Chi- } \\
\text { cago }\end{array}$ & $\mathbf{A}$ & B & $\mathbf{x}$ \\
\hline $\begin{array}{l}\text { Cough } \\
\begin{array}{l}\text { Less .. } \\
\text { No change }\end{array} \\
\text { Worse } \\
\text { No data and deaths }\end{array}$ & $\begin{array}{r}30 \\
39 \\
7 \\
24\end{array}$ & $\begin{array}{r}13 \\
22 \\
3 \\
12 \\
\end{array}$ & $\begin{array}{r}17 \\
17 \\
4 \\
12\end{array}$ & $\begin{array}{r}10 \\
18 \\
3 \\
11\end{array}$ & $\begin{array}{l}8 \\
8 \\
1 \\
8\end{array}$ & $\begin{array}{r}12 \\
13 \\
3 \\
5\end{array}$ \\
\hline $\begin{array}{l}\begin{array}{l}\text { Sputum production } \\
\text { (history) } \\
\text { Less.. } \\
\text { No change } \ldots\end{array} \\
\text { More... } \\
\text { No data and deaths }\end{array}$ & $\begin{array}{r}36 \\
31 \\
8 \\
25\end{array}$ & $\begin{array}{r}16 \\
18 \\
3 \\
13\end{array}$ & $\begin{array}{r}20 \\
13 \\
5 \\
12\end{array}$ & $\begin{array}{r}13 \\
14 \\
4 \\
11\end{array}$ & $\begin{array}{l}8 \\
8 \\
1 \\
8\end{array}$ & $\begin{array}{r}15 \\
9 \\
3 \\
6\end{array}$ \\
\hline $\begin{array}{l}\text { Sputum vol. (measured) } \\
\text { Less .. } \ldots \\
\text { No change } \\
\text { More . . } \\
\text { No data and deaths }\end{array}$ & $\begin{array}{l}22 \\
32 \\
13 \\
33\end{array}$ & $\begin{array}{r}12 \\
12 \\
7 \\
19\end{array}$ & $\begin{array}{r}10 \\
20 \\
6 \\
14\end{array}$ & $\begin{array}{r}4 \\
16 \\
7 \\
15\end{array}$ & $\begin{array}{l}9 \\
6 \\
1 \\
9\end{array}$ & $\begin{array}{r}9 \\
10 \\
5 \\
9\end{array}$ \\
\hline $\begin{array}{l}\text { Breathlessness (history) } \\
\begin{array}{l}\text { Less } . . \\
\text { No change }\end{array} \\
\text { Worse } \\
\text { No data and deaths }\end{array}$ & $\begin{array}{l}13 \\
36 \\
27 \\
24\end{array}$ & $\begin{array}{r}10 \\
19 \\
9 \\
12\end{array}$ & $\begin{array}{r}3 \\
17 \\
18 \\
12\end{array}$ & $\begin{array}{r}5 \\
14 \\
12 \\
11\end{array}$ & $\begin{array}{r}2 \\
11 \\
4 \\
8\end{array}$ & $\begin{array}{r}6 \\
11 \\
11 \\
5\end{array}$ \\
\hline 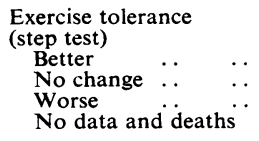 & $\begin{array}{l}20 \\
35 \\
20 \\
25\end{array}$ & $\begin{array}{r}10 \\
20 \\
8 \\
12\end{array}$ & $\begin{array}{l}10 \\
15 \\
12 \\
13\end{array}$ & $\begin{array}{r}8 \\
12 \\
10 \\
12\end{array}$ & $\begin{array}{r}4 \\
10 \\
3 \\
8\end{array}$ & $\begin{array}{r}8 \\
13 \\
7 \\
5\end{array}$ \\
\hline $\begin{array}{l}\text { Oedema (history) } \\
\text { Absent throughout } \\
\text { Present before first } \\
\text { interview subse- } \\
\text { quently improved } \\
\text { Present before first } \\
\text { interview and sub- } \\
\text { sequently .. } \\
\text { Absent before first } \\
\text { interview-subse- } \\
\text { quently developed } \\
\text { No data or deaths... }\end{array}$ & $\begin{array}{l}18 \\
24\end{array}$ & $\begin{array}{r}8 \\
12\end{array}$ & $\begin{array}{l}10 \\
12\end{array}$ & $\begin{array}{l}12 \\
11\end{array}$ & $\begin{array}{l}3 \\
8\end{array}$ & 14 \\
\hline
\end{tabular}

ficantly correlated with increase in airway obstruction as reflected in the regression of F.E.V $\cdot \cdot \cdot 0$ with time $(\mathrm{r}=-0.477 ; \mathrm{P}<0.001)$.

EXACERBATIONS OF BRONCHITIC SYMPTOMS There was a marked difference between the two clinics in the answers obtained to questions regarding chest illnesses (Table VA). London patients reported almost twice as many illnesses causing time off work or a stay in bed as the Chicago patients, and almost three times as many London patients had more than two such illnesses each year. In order to look into this question more closely, self-completion questionnaires were sent to the patients every three months to obtain details of increases in bronchitic symptoms. The replies obtained to three such questionnaires sent in 1962-63 were compared. It was found (Table VB) that the number of such exacerbations was only slightly higher in London; a similar proportion of the episodes were associated with a report of yellow sputum and an increase in breathlessness and malaise, but fever was more common in London patients. London patients went to bed more frequently during these episodes (39 patients compared with 14 in Chicago) and for much longer than their Chicago counterparts ; about three times as many London patients took time off work because of chest illnesses. Thus the frequency of exacerbations of bronchitic symptoms was actually not as different in the two clinics as the answers to the annual questionnaires had suggested. The answers to the quarterly questionnaires demonstrated that the main difference between the two clinics was not so much a difference in the number or characteristics of such exacerbations as in the number of times they led to the patient staying in bed or off work.

OCCUPATION The first survey showed that patients in the two clinics had a similar range of occupa- $\vec{\bullet}$ tions; changes in occupation were also similar (Table VI). Of 64 patients who were initially working and were followed for more than two years, 25 stopped working because of chest symptoms ; the changes in clinical and physiologi-

T A B LE IV

A. Comparison of change of sputum volume with change in history of sputum

\begin{tabular}{|c|c|c|c|c|c|c|c|}
\hline \multirow{2}{*}{\multicolumn{4}{|c|}{$\begin{array}{l}\text { Change of Observed } \\
\text { Sputum Vol. }\end{array}$}} & \multicolumn{4}{|c|}{ Change in History of Sputum } \\
\hline & & & & Less & Same & More & Total \\
\hline $\begin{array}{l}\text { Reduction } \\
\text { No change } \\
\text { Increase }\end{array}$ & $\begin{array}{l}\cdots \\
\cdots\end{array}$ & $\begin{array}{l}\cdots \\
\cdots \\
\cdots\end{array}$ & $\begin{array}{l}\cdots \\
\cdots \\
\cdots\end{array}$ & $\begin{array}{r}12 \\
18 \\
3\end{array}$ & $\begin{array}{r}7 \\
12 \\
8\end{array}$ & $\begin{array}{l}3 \\
2 \\
2\end{array}$ & $\begin{array}{l}22 \\
32 \\
13\end{array}$ \\
\hline Total .. & $\ldots$ & $\ldots$ & $\ldots$ & 33 & 27 & 7 & 67 \\
\hline
\end{tabular}

B. Comparison of change of dyspnoea by history and by observation of step test

\begin{tabular}{|c|c|c|c|c|c|c|c|}
\hline \multirow{2}{*}{\multicolumn{4}{|c|}{$\begin{array}{l}\text { Change in History } \\
\text { of Dyspnoea }\end{array}$}} & \multicolumn{4}{|c|}{ Change of Step Test Dyspnoea } \\
\hline & & & & \multirow{2}{*}{$\begin{array}{c}\text { Better } \\
6 \\
13 \\
. \quad 1\end{array}$} & \multirow{2}{*}{$\begin{array}{r}\text { Same } \\
6 \\
15 \\
14\end{array}$} & \multirow{2}{*}{$\begin{array}{c}\text { Worse } \\
0 \\
8 \\
12\end{array}$} & \multirow{2}{*}{$\begin{array}{c}\text { Total } \\
12 \\
36 \\
25\end{array}$} \\
\hline $\begin{array}{l}\text { Better .. } \\
\text { Same .. } \\
\text { Worse. . }\end{array}$ & $\begin{array}{l}\cdots \\
\cdots\end{array}$ & $\begin{array}{l}\cdots \\
\cdots \\
\cdots\end{array}$ & $\begin{array}{l}\cdots \\
\cdots \\
\cdots\end{array}$ & & & & \\
\hline Total $\ldots$ & . & . & . & 20 & 35 & 20 & 75 \\
\hline
\end{tabular}

C. Comparison of change of F.E.V.1.0 with change of step test dyspnoca

\begin{tabular}{|c|c|c|c|c|}
\hline \multirow{2}{*}{ Change in F.E.V.1.0 } & \multicolumn{4}{|c|}{ Change of Step Test Dyspnoea } \\
\hline & Better & Same & Worse & Total \\
\hline $\begin{array}{l}\text { Increase of } 0.21 \text {. or more } \ldots \\
\text { No change } 0.21 . \text { or more } \ldots \\
\text { Decrease of } 0.21\end{array}$ & $\begin{array}{r}5 \\
14 \\
1\end{array}$ & $\begin{array}{r}1 \\
24 \\
10\end{array}$ & $\begin{array}{r}1 \\
4 \\
15\end{array}$ & $\begin{array}{r}7 \\
42 \\
26\end{array}$ \\
\hline Total $\ldots$ & 20 & 35 & 20 & 75 \\
\hline
\end{tabular}

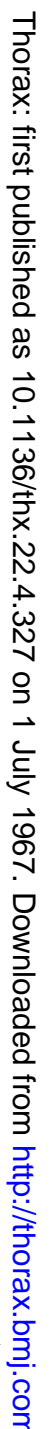




\section{T A B L E V}

INCIDENCE OF CHEST ILLNESSES IN THE TWO CLINICS, GAINED FROM TWO QUESTIONNAIRES

A. Annual questionnaire

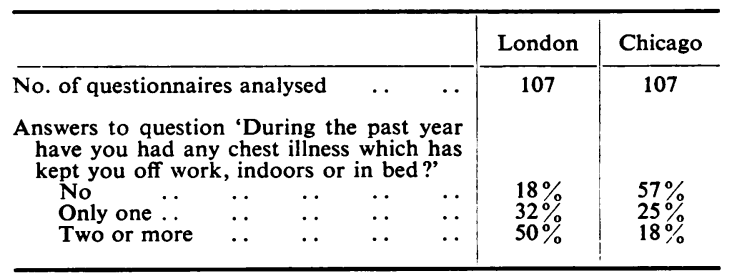

B. Quarterly self-completion questionnaire (Oct. 1962-June 1963)

\begin{tabular}{|c|c|c|c|c|}
\hline \multirow{3}{*}{$\begin{array}{c}\text { No. of questionnaires } \\
\text { analysed } \ldots\end{array}$} & \multicolumn{2}{|c|}{ London } & \multicolumn{2}{|c|}{ Chicago } \\
\hline & \multicolumn{2}{|c|}{95} & \multicolumn{2}{|c|}{106} \\
\hline & Total & $\begin{array}{c}\% \\
\text { Patients } \\
\text { answer- } \\
\text { ing Yes } \\
\text { to } 1 .\end{array}$ & Total & $\begin{array}{l}\text { \% } \\
\text { Patients } \\
\text { answer- } \\
\text { ing Yes } \\
\text { to } 1 .\end{array}$ \\
\hline $\begin{array}{l}\text { Positive answers to questions: } \\
\text { 1. 'Did you have more sputum } \\
\text { than usual for a period of } \\
\text { one week or more?' } \\
\text { If 'Yes' to question 1, then } \\
\text { (a) 'Was the sputum more } \\
\text { yellow than usual?' } \\
\text { (b) 'Were you more breath- } \\
\text { less than usual?' } \\
\text { (c) 'Did you feel generally } \\
\text { unwell?' } \\
\text { (d) 'Did you have an ele- } \\
\text { vated temperature?' } \\
\text { (e) 'Did you stay in bed?' } \\
\text { (f) 'For how many, days } \\
\text { were you in bed?' } \\
1-3 \quad . \quad \ldots \\
3-7.0 \\
\text { More than } 7 \\
\text { 2. 'Have you lost any time off } \\
\text { work?' } \\
\quad . .\end{array}$ & 52 & $\begin{array}{r}100 \\
\\
55 \\
94 \\
92 \\
34 \\
82^{1} \\
\\
9 \\
47 \\
26\end{array}$ & 16 & $\begin{array}{r}100 \\
70 \\
98 \\
86 \\
21 \\
33 \\
\\
14 \\
5 \\
12\end{array}$ \\
\hline
\end{tabular}

139 London patients $(74 \%)$ gave positive answers to question $1(\mathrm{c})$ : 5 patients had two episodes, a total of $44(82 \%)$

T A B L E V I

CHANGES IN OCCUPATION

\begin{tabular}{l|c|c|c|c}
\hline & London & Chicago & Total \\
\hline Still working $\ldots$ & \multicolumn{1}{|c|}{$\ldots \quad \ldots$} & 18 & 21 & 39 \\
Stopped because of chest symptoms $\ldots$ & 12 & 13 & 25 \\
Not working before or retired & $\ldots$ & 8 & 6 & 14 \\
No data for 2-3 yrs (including deaths) & 12 & 10 & 22 \\
\hline
\end{tabular}

cal findings in the patients who stopped working were not significantly different from those in the patients who continued to work.

SMOKING HABITS These were very similar in the two clinics. Most patients had already reduced their cigarette consumption before the study began ; $50 \%$ had stopped smoking and only $5 \%$ were smoking more than 20 cigarettes per day. During the follow-up period a further 17 patients, who were smoking small numbers of cigarettes, stopped. No difference was observed between those who had stopped and those who had continued to smoke in respect of cough, sputum, dyspnoea, or physiological tests.

RADIOLOGY In the patients originally classed as showing radiological emphysema, no radiographic changes were noted. Inflammatory changes, presumably due to atelectasis or subacute bronchopneumonia, increased in the radiographs of two patients and improved in one. No patient developed radiological signs of emphysema during the follow-up. An increase of more than $1 \mathrm{~cm}$. in the transverse diameter of the heart was found in 10 patients: a similar decrease occurred in three.

ELECTROCARDIOGRAPHY Signs of right ventricular hypertrophy (grades 2 to 4 changes, Goodwin and Abdin, 1959) developed in five patients. In all but one this was associated with symptomatic deterioration together with a fall in F.E.V $\cdot_{\cdot 1 \cdot 0}$ of over 0.21 . and an increase in $\mathbf{P} \overline{\mathrm{CO}_{2}}$ of over 5 $\mathrm{mm}$. $\mathrm{Hg}$.

CHANGES IN PULMONARY FUNCTION Many patients showed a fall in F.E.V $\cdot_{\cdot 1 \cdot 0}$ in the three years, the average decline being $0.046 \mathrm{l}$. per year (Table VII). In 26 patients $(34 \%)$ the reading at the last follow-up was more than $0.2 \mathrm{l}$. below the initial reading; seven showed a similar increase. The regressions of F.E.V.1.0 and V.C. with time in individual patients were negatively correlated with the initial F.E.V..$_{1 \cdot 0}$ and V.C. $(r=0.321 ; P<0.01$ and $r=-0.265 ; P<0.05$ respectively). Since it is fallacious to relate a change of a variable to its initial value (Oldham, 1962) we have examined the correlation between change of F.E.V..$_{1 \cdot 0}$ and V.C. and the average value during the follow-up period. Change of F.E.V.$_{\cdot 1 \cdot 0}$ was not significantly correlated with the mean value $(r=+0.076$; $P<0 \cdot 1)$ but the change of V.C. was positively related to the average value $(r=+0.205$; $\mathbf{P}<0.05$ ). That is, the lower the average V.C. the faster it tended to decline. The fall in V.C. was slightly less in Chicago than in London patients, but this difference was not significant.

Mixed venous $\mathrm{PCO}_{2}$ increased on average by almost $1 \mathrm{~mm}$. $\mathrm{Hg}$ per year; over the two- to three-year period an increase of more than 5 $\mathrm{mm}$. $\mathrm{Hg}$ occurred in nine London patients $(24 \%)$ 
T A B L E V I I

RESPIRATORY FUNCTION

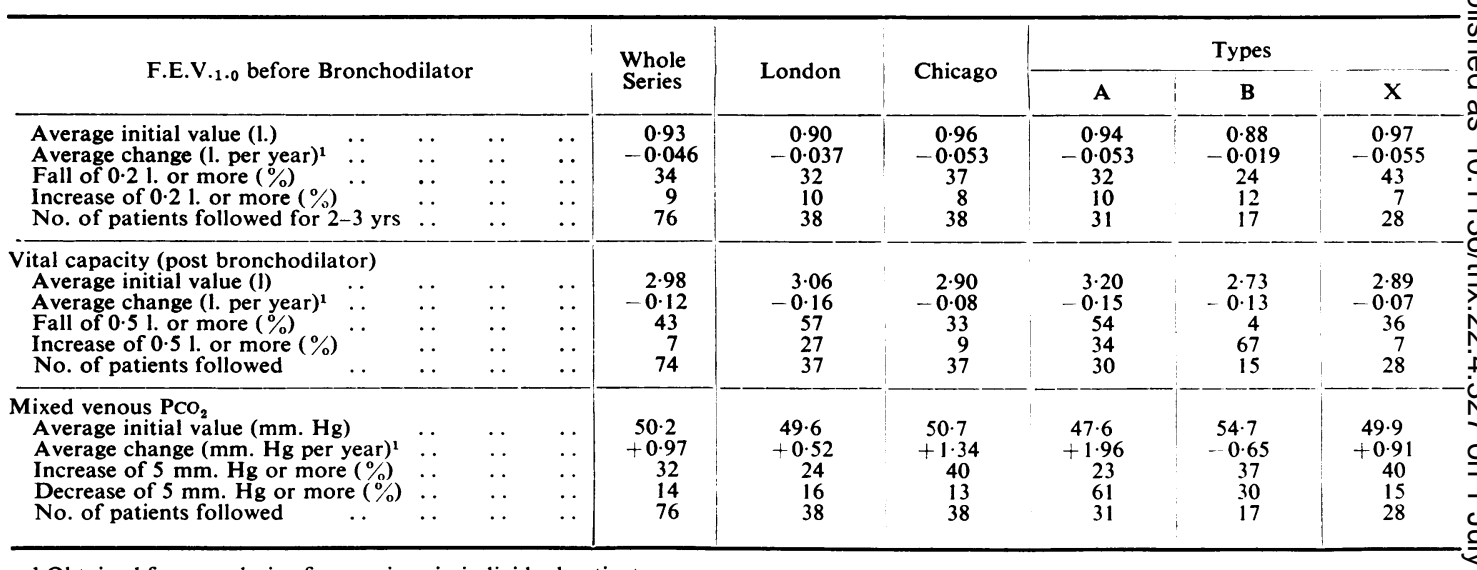

1 Obtained from analysis of regressions in individual patients

and in 15 Chicago patients (39\%) (difference not significant). Of the 24 patients in whom $\mathrm{P} \mathrm{vCO}_{2}$ increased by more than $5 \mathrm{~mm}$. $\mathrm{Hg}, 14$ showed a fall in F.E.V $\cdot_{1 \cdot 0}$ of more than 0.21 . and the regressions of $\mathrm{P}_{\overline{\mathrm{V}} \mathrm{CO}_{2}}$ and F.E.V. ${ }_{\cdot 1 \cdot 0}$ were just significantly correlated $(\mathrm{r}=-0.261 ; \mathrm{P}<0.05)$.

COMPARISON OF CLINICAL TYPES OF PATIENT When the courses of the three clinical types of patient were compared it was found that the death rate was highest in type B patients (Table VIII). This finding could not be related entirely to the degree of airway obstruction as indicated by the F.E.V.$_{1 \cdot 0}$; even when patients with an F.E.V ${ }_{\cdot 1 \cdot 0}$ of less than 1 litre were considered (Fig. 1) the death rate was higher in group $B$ than in the other groups and appeared to be similarly related to F.E.V. $\cdot_{\cdot 1 \cdot 0}$ in all three types. The relation between death and the initial $\mathrm{P}_{\overline{\mathrm{V}}} \mathrm{CO}_{2}$ has already been mentioned (Fig. 2): stepwise regression showed that after the $\mathrm{P}_{\overline{\mathrm{V}}} \mathrm{CO}_{2}$ had been considered there was no significant correlation with the type of patient. Chronic or recurrent heart failure had been present in four of the nine type $B$ patients who

T A B LE V I I I

INCIDENCE OF DEATHS ACCORDING TO CLINICAL TYPE OF PATIENT

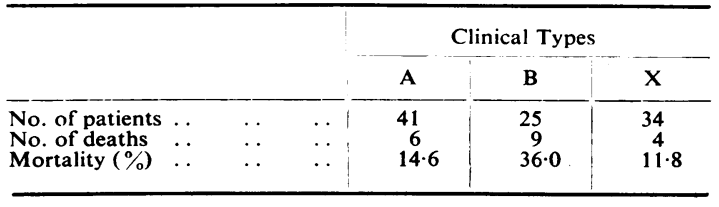

died, compared to one of the six type A patients; in all these patients the initial $\mathrm{P} \bar{v} \mathrm{CO}_{2}$ was $55 \mathrm{~mm}$. O $\mathrm{Hg}$ or more. Apart from these differences the clinical types of patient behaved in a very similar way during the follow-up period. The slight $\frac{0}{D}$ differences between the types in the progression of symptoms and of pulmonary function abnormalities were not significant.

\section{DISCUSSION}

The mortality rate found in this study-26\% over a three-year period-is approximately four times higher than that expected in the general popula- 3 tion of England and Wales (Registrar General's Siatistical Review, 1964). It is similar to the report by Oswald, Medvei, and Waller (1967) of 70\% mortality over 10 years in 148 moderately or severely disabled patients aged 45-65. Bates, Knott, $\frac{D}{0}$ and Christie (1956), Boushy and Lewis (1964), and Mitchell, Webb, and Filley (1964) recorded very o similar findings. The initial findings in our $19 \mathrm{~N}$ patients who died of their respiratory disease $N$ showed considerable overlap with those of the ${ }^{\omega}$ survivors, but these patients tended to be more? short of breath with a lower average F.E.V. . (Fig. 1), higher average $\mathrm{P}_{\bar{v}} \mathrm{CO}_{2}$ (Fig. 2), and a greater incidence of congestive heart failure and of electrocardiographic and radiographic abnormality. The relationship between blood gas changes and cor pulmonale has previously been $\frac{?}{\Phi}$ reported by Platts and Greaves (1957) among $\varrho$ others. The prognostic significance of severe dys pnoea, airway obstruction, and blood gas distur- 
bances was shown by Mitchell et al. (1964) and Boushy and Coates (1964); our statistical correlations suggested that, of the factors we measured, $\mathbf{P} \mathrm{CO}_{2}$ was the most important in prognosis. The initial total lung capacity was lower in the patients who subsequently died, but the average diffusing capacity for $\mathrm{CO}$ was similar to that of the patients who survived. The overlap in the findings makes it difficult to ascribe prognostic importance to any one factor. A similar overlap was found by Bates et al. (1956), who followed up 59 patients for three years. They found, however, in contrast to the present results, that severe reduction in the diffusing capacity for $\mathrm{CO}$ was a serious prognostic sign; Sukumalchantra and Williams (1965) also noted this in a retrospective study of 44 patients. The difference between our study and these previous reports may be due partly to differences in selection. Patients with cor pulmonale were excluded from the study of Bates et al. (1956), so that fewer type B patients, with relatively well-preserved Dico, would be expected to appear in their study. Differences in technique may contribute to our differing findings; DLco was measured by the single-breath technique in our patients and by steady-state methods in these other studies.

In considering changes in symptoms, it must be remembered that patients who died have been excluded from our analysis unless they were still alive after two to three years. During the followup period neither cough nor sputum production changed much. About $40 \%$ became more breathless either symptomatically or as judged by the step test (Table III), and in $15 \%$ deterioration was noted in both symptoms and performance (Table IV). In most patients an increase in breathlessness was accompanied by a decrease in ventilatory capacity, being significantly related to a fall in F.E.V. $\cdot 1 \cdot 0(P<0 \cdot 001)$. Change in observed exercise dyspnoea correlated with decrease of F.E.V ${ }_{\cdot 1 \cdot ?}$ $(\mathbf{P}<0.001)$, but also correlated with decrease of V.C. $(\mathbf{P}<0.01)$ and increase of $\mathrm{P}_{\overline{\mathrm{V}} \mathrm{CO}}(\mathbf{P}<0.05)$. In a small number of patients (7 to $10 \%$ ) an improvement occurred in symptoms, observed dyspnoea, and ventilatory capacity. In some, this was due to control of bronchial infection but in others it may have been due to random variation in disability and pulmonary function; it does not appear to be due merely to the beneficial effect which might be expected after enrolment in a special clinic, for nearly all the patients had been attending the same clinic for some years before the study began. There is no doubt that even at this advanced stage a few patients will be found to improve.
Oedema was noted for the first time during the follow-up period by 18 patients in whom it had been absent initially (Table III). An increase in heart size in the chest radiograph was found in four of these patients, but an increase in electrocardiographic signs of right ventricular hypertrophy in only one; these changes occurred with almost equal frequency in patients who did not develop oedema.

It is well known that cessation of smoking will often lead to clinical improvement in patients with chronic airway obstruction. A large proportion of our patients had stopped smoking before the study began and almost all had cut their consumption to a low level; those who stopped during the study showed similar progress to those who continued, but the small numbers make it impossible to draw any general conclusions regarding the effects of stopping smoking small numbers of cigarettes.

Few changes in the radiographic appearances were seen: in their study of a large number of patients, Simon and Medvei (1962) drew attention to the lack of progression in radiographic appearances and were unable to find any patient who developed radiological changes of emphysema during a five-year period.

Although considerable variation was found, there was on average a yearly decline in V.C. of 0.12 l. and in the F.E.V.1.0 0.046 litre. The latter figure is less than that found by the Medical Research Council's working party (1966) in a study of 373 men with early bronchitis in which F.E.V..$_{1 \cdot 0}$ declined at a mean rate of 0.0821 . per year. It is, however, much greater than the average rate of $0.025 \mathrm{l}$. per year found by Fletcher et al. (unpublished) in working men. The initial F.E.V ${ }_{\cdot 1 \cdot 0}$ in these groups was higher than that of the patients in the present study: the yearly decrease in F.E.V $.1 \cdot 0$ when expressed as a percentage of the initial value was $4.8 \%$ in our study compared with $4.0 \%$ in the M.R.C. report and less than $1 \%$ in working men. There was little change in $\mathrm{P} \overline{\mathrm{v}} \mathrm{CO}_{2}$ during the study (an average yearly increase of about $1 \mathrm{~mm} . \mathrm{Hg}$ ); the regression in $\mathrm{P}_{\overline{\mathrm{v}}} \mathrm{CO}_{2}$ was related to the regression in F.E.V. ${ }_{\cdot 1 \cdot 0}(P<0.05)$, and the average $\mathrm{P}_{\mathbf{V}} \mathrm{CO}_{2}$ during the follow-up period was related to both F.E.V. $\cdot_{1 \cdot 0}$ and V.C. $(P<0.001)$, confirming the relationships between these measurements (Burrows, Niden, Barclay, and Kasik, 1965). Previous retrospective studies of changes in pulmonary function in patients with chronic airway obstruction have shown little change in lung 
volumes and blood gases; however, Boushy and Lewis (1964) and Sukumalchantra and Williams (1965) reported that small but significant changes occurred in diffusing capacity over several years. Single-breath Duco was measured during the study in the 38 surviving Chicago patients; the average fall over two to three years was $2.6 \mathrm{ml}$. $/ \mathrm{min}$./ $\mathrm{mm} . \mathrm{Hg}$, and 11 patients showed a fall of over 5 $\mathrm{ml} / \mathrm{min} . / \mathrm{mm}$. $\mathrm{Hg}$ during the follow-up period; $\mathrm{D}_{\mathrm{L}} / \mathrm{V}_{\Lambda}$, the diffusing capacity per litre of lung volume, fell on average by $0.37 \mathrm{ml} / \mathrm{min} . / \mathrm{mm}$. $\mathrm{Hg} / \mathrm{l}$.; these figures are in agreement with those of previous reports which used steady-state methods for measuring $D_{\text {LCO. No }}$ consistent relation could be found between the fall in $\mathrm{D}_{\mathrm{LCO}}$ and a fall in F.E.V. ${\cdot \cdot_{10}}$ or V.C. in individual patients.

In most respects the patients in the two cities showed a similar progression during the study, confirming the similarity of patients with irreversible airway obstruction in London and Chicago (Fletcher et al., 1964). Methods of treatment were much the same in the two clinics apart from a freer use of wide-spectrum antibiotics in London. The death rate was similar and the necropsy findings in those patients whose death could be directly attributed to their chest illness were also similar. A wide range of severity of emphysematous changes was found in patients from both clinics, from little or no emphysema to severe panacinar emphysema involving most of the lungs. We have already reported the relationships between clinical, physiological, and anatomical findings (Burrows et al., 1966).

There were few differences in the course of the survivors in the two clinics. A higher proportion of Chicago patients claimed an improvement in their cough and dyspnoea, but the changes in objective tests were not significantly different in the two clinics. In the initial study a greater frequency of disabling 'chest illnesses' was found in London; this was fully confirmed in the present study. The more detailed three-monthly questionnaires revealed that the number of such illnesses were similar in the two groups, but that London patients spent more time off work and in bed. This is presumably related to various differences in social and economic conditions between the two cities, including working conditions, sickness benefits, and cost of treatment, but we have no evidence regarding the relative importance of such factors. However, it is possible that some of the differences between the clinics is due to more severe illness in London: the reported incidence of fever was slightly higher in British patients, but that of other symptors appeared to be similar.
We are grateful for the assistance of many colleagues, in particular Dr. G. J. R. McHardy, who have helped in our co-operative study. The work was supported in Chicago by U.S.P.H.S. grant H04109 and in London by a grant from the Chest and Heart Association. Assistance in computation was provided by the Biological Sciences Computation Center, University of Chicago, under U.S.P.H.S. grant FR00013.

\section{REFERENCES}

Bates, D. V., Knott, J. M. S., and Christie, R. V. (1956). Respiratory function in emphysema in relation to prognosis. Quart. J. Med., $25,137$.

Boushy, S. F., and Coates, E. O. (1964). The prognostic value of pulmonary function tests in emphysema, with special reference to arterial blood studies. Amer. Rev. resp. Dis., 90, 553. and Lewis, B. M. (1964). The natural history of emphysema. Geriatrics, 19, 910.

Burrows, B., Fletcher, C. M., Heard, B. E., Jones, N. L., and Wootliff, J. S. (1966). The emphysematous and bronchial types of chronic airway obstruction. Lancet, 1, 830 .

- Niden, A. H., Fletcher, C. M., and Jones, N. L. (1964). Clinical types of chronic obstructive lung disease in London and in Chicago. Amer. Rev. resp. Dis., 90, 14

Barclay, W. R., and Kasik, J. E. (1965). Chronic obstructive lung disease. II. Relationship of clinical and physiologic findings to the severity of airways obstruction. Ibid., 91, 665 .

Campbell, E. J. M., and Howell, J. B. L. (1960). Simple rapid methods of estimating arterial and mixed venous $\mathrm{pCO}_{2}$. Brit. med.J., $1,458$.

Fletcher, C. M., Jones, N. L., Burrows, B., and Niden, A. H. (1964). American emphysema and British bronchitis: A standardized comparative study. Amer. Rev. resp. Dis., 90, 1.

Goodwin, J. F., and Abdin, Z. H. (1959). The cardiogram of congenital and acquired right ventricular hypertrophy. Brit. Heart J., $21,523$.

Medical Research Council (1966). A report to the Medical Research Council by their Working Party on trials of chemotherapy in early chronic bronchitis. Brit. med. J., 1, 1317.

Mitchell, R. S., Webb, N. C., and Filley, G. F. (1964). Chronic obstructive bronchopulmonary disease. III. Factors influencing prognosis. Amer. Rev. resp. Dis., 89, 878.

Oldham, P. D. (1962). A note on the analysis of repeated measurements of the same subjects. J. chron. Dis., 15, 969.

Oswald, N. C., Medvei, V. C., and Waller, R. E. (1957). Chronic bronchitis: a 10-year follow-up. Thorax, 22, 279.

Platts, M. M., and Greaves, M. S. (1957). Arterial blood gas measurements in the management of patients with chronic bronchitis and emphysema. Ibid., 12, 236.

Simon, G., and Medvei, V. C. (1962). Chronic bronchitis: radiclogical aspects of a five-year follow-up. Ibid., 17, 5 .

Sukumalchantra, Y., and Williams, M. H. (1965). Serial studies of pulmonary function in patients with chronic obstructive pulmonary disease. Amer. J. Med., 39, 941.

\section{APPENDIX}

CRITERIA FOR THE DIAGNOSIS OF CLINICAL TYPES OF PATIENT WITH SEVERE IRREVERSIBLE AIRWAY $Q$ OBSTRUCTION (F.E.V.1.0 LESS THAN 1.5 1.) (Burrows et al., 1966)

Type $A$ (severe emphysema) Either (1) radiological evidence of generalized emphysema- $\stackrel{\mathbb{D}}{\Omega}$ definite attenuation of the peripheral vascular $\underset{\mathbb{D}}{\mathbb{8}}$ pattern as defined by Laws and Heard (Brit. J. $\frac{\Omega}{0}$ Radiol., 1962, 35, 750) unaccompanied by chronic inflammatory changes ; or (2) normal chest radio- 
graph in the absence of type B criteria $2,3,4$, and 5 below.

Type $B$ (mild or absent emphysema) No radiological evidence of emphysema but with at least three of the following:

(1) sputum volume persistently more than 10 ml./day ;

(2) persistent hypercapnia-defined as a $\mathrm{PCO}_{2}$ at least $6 \mathrm{~mm}$. $\mathrm{Hg}$ above the level predicted from the F.E.V.$_{1 \cdot 0}$ (Burrows et al., 1965);
(3) radiological evidence of chronic inflammatory disease in the lung parenchyma ;

(4) total lung capacity less than $100 \%$ predicted ;

(5) diffusing capacity for $\mathrm{CO}$ not grossly reduced $\left(\mathrm{D}_{\mathrm{L}} / \mathrm{V}_{\mathrm{A}}\right.$ of $3.5 \mathrm{ml} . / \mathrm{min} . / \mathrm{mm}$. $\mathrm{Hg}$. $/ \mathrm{l}$. or more) ;

(6) chronic or recurrent right heart failure.

Type $X$ (indeterminate) Patient cannot be designated as type A or B using the criteria. 